\title{
Plasticity in the diet of two echinoderm species across an ecotone: microbial recycling of forest litter and bottom-up forcing of population structure
}

\author{
Stephen R. Wing ${ }^{1, *}$, Rebecca J. McLeod ${ }^{1}$, Kim L. Clark ${ }^{1}$, Russell D. Frew ${ }^{2}$ \\ ${ }^{1}$ Department of Marine Science, and ${ }^{2}$ Department of Chemistry, University of Otago, PO Box 56, Dunedin, New Zealand
}

\begin{abstract}
Many coastal marine populations persist across gradients in benthic productivity. In the New Zealand fjords there is a sharp gradient in available biomass between the wave-washed outer coasts, dominated by kelps, and the quiescent inner fjords, where estuarine seaweeds and terrestrial inputs predominate. In Doubtful Sound we found significant variation in abundance of macroalgal groups, the grazing sea urchin Evechinus chloroticus and the detritivorous sea cucumber Stichopus mollis, and in $\delta^{15} \mathrm{~N}$ and $\delta^{13} \mathrm{C}$ of the macroalgae and consumers among 5 study sites across this gradient. Analysis of $\delta^{15} \mathrm{~N}$ and $\delta^{13} \mathrm{C}$ from tissue of the 2 consumers relative to the primary carbon source pools with a mass balance model indicated that diet was primarily influenced by composition and quality of macroalgal food, except at the innermost sites, where there was evidence for terrestrial inputs. These results demonstrate that it is important to resolve relative abundance of food sources and specific isotopic variation to resolve spatial patterns in diet from stable isotope analysis across environmental gradients. Isotopic analysis of $E$. chloroticus stomach contents from the innermost sites provided strong evidence that terrestrial detritus was being assimilated via microbial recycling $\left(\delta^{15} \mathrm{~N},-5 \%\right.$ and $\delta^{13} \mathrm{C}_{\text {, }}$ $-37 \%$ ). Differences in $\delta^{13} \mathrm{C}$ of stomach contents versus those of tissues provided a basis to measure assimilation. There was a strong correlation between this proxy for assimilation with growth parameters among study sites across the ecotone. This analysis indicates a strong bottom-up influence on vital rates of E. chloroticus within the fjord, with links to the source-sink structure of the population.
\end{abstract}

KEY WORDS: Benthic food web $\cdot$ Fjord $\cdot$ Stable isotopes $\cdot$ Productivity gradient $\cdot$ Bacteria $\cdot$ Forest litter

\section{INTRODUCTION}

Though metapopulations of many benthic marine invertebrates are profoundly influenced by the physical patterns of transport and supply of propagules from one population to another (Hixon et al. 2002), the difference in habitat quality among adult populations and its influence on local reproductive output, giving rise to regional variability in production of larvae, is an equally vital structuring mechanism (Hanski \& Gaggiotti 2004). This is particularly apparent across environmental gradients where benthic marine invertebrates may be subject to profound variations in abundance and quality of food (Vadas 1977, Lamare \& Wing 2001, Wing et al. 2001). In this case, bottom-up forcing of local vital rates, particularly growth and reproductive output, may result in a disparity between source and supply of larvae, or a source-sink population structure (Wing et al. 2003a,b). An example of one such situation is in the New Zealand fjords, where sea urchins Evechinus chloroticus form a continuous distribution on rocky reef habitats from the wave-exposed outer coastal areas where kelps dominate benthic production to the quiescent inner reaches of the fjords where riverine and terrestrial influences become prevalent (McLeod \& Wing 2007). This ecotone between terrestrial and marine systems provides important structure, and consequently influences diversity and variability in vital rates within populations and the benthic marine food web. 
Fjords are excellent model ecological systems for studies of the flow of energy and materials as their geomorphology, climate and communities are interconnected through distinct and proximate compartments (Burrell 1988, Ross et al. 1993). Fourteen fjords that support diverse and highly endemic marine communities (Southwood 1977, Smith \& Witman 1999, Smith 2001) indent the southwestern coast of New Zealand. Because freshwater influx is large and environmental gradients are compressed, individual fjords harbour many of southern New Zealand's coastal habitats, including native forest catchments, freshwater, estuarine, exposed rocky reef and deep-benthic mud flats in each semi-enclosed basin.

Environmental gradients within the fjords are extreme. For example, along the Fiordland coast, mountain peaks of over $1000 \mathrm{~m}$ in altitude descend as steep granite faces to the sea where they extend to deepwater basins of up to $450 \mathrm{~m}$ depth. This region is also characterised by high rainfall, up to $7 \mathrm{~m} \mathrm{yr}^{-1}$, resulting in substantial runoff that arrives at the sea after passing through thick native beech forests (Nothofagus spp.). The tannin-stained runoff accumulates on the surface of the fjords, forming a distinct surface lowsalinity layer (LSL) (Stanton \& Pickard 1981). Estuarine circulation, reduced salinity and light attenuation of the LSL play important roles in modifying the distribution and abundance of macroalgae and sessile invertebrates with respect to depth and distance along the fjord axis (Witman \& Grange 1998, Smith \& Witman 1999, Wing et al. 2001). Carbon sources from forest litter and estuarine algae are more prevalent in inner fjord areas (McLeod \& Wing 2007), while the presence of dense macroalgal assemblages in outer fjord areas supports an abundant kelp forest community (Nelson et al. 2002, Miller et al. 2006, Wing et al. 2007). These differences in the origin and availability of resources have a strong influence on subtidal community structure and routing of carbon through the benthic food web.

The observed variability in quantity and apparent lability of carbon sources from the outer coast to the inner fjord region present an interesting question. The sea urchin Evechinus chloroticus exists in a continuous distribution from the outer coast to the innermost fjord habitats. While the adult populations in the inner fjords receive high rates of settlement due to enhanced larval retention within the fjord basins by estuarine circulation (Lamare 1998, Wing et al. 2003a), available food is relatively scarce and of poor quality (Lamare \& Mladenov 2000, Lamare \& Wing 2001). How, then, is the adult population maintained across this strong gradient in food resources?

Because diet is the principal determinant of isotopic compositions of animal tissues, isotopic ratios of carbon and nitrogen can be used to infer sources of organic matter to consumers (Peterson \& Howarth 1987, Peterson 1999, Fry 2006). Moreover, information on patterns in flux of organic matter can be obtained by examining the enrichment of ${ }^{13} \mathrm{C}$ and ${ }^{15} \mathrm{~N}$ isotopes as they move through the food web (Post 2002). To this end, ecologists have used stable isotope analyses to investigate energy sources and flux within a wide variety of ecosystems (Rounick \& Winterbourn 1986, Peterson \& Fry 1987). Multiple stable isotopes of carbon, nitrogen and sulphur have been used extensively to resolve spatial gradients in resource use in rivers (Rounick et al. 1982), estuaries (Peterson et al. 1985, Peterson \& Howarth 1987, Deegan \& Garritt 1997, Machás \& Santos 1999, Hughes et al. 2000, McKee et al. 2002) and in coastal and open ocean systems (Dunton et al. 1989, Saupe et al. 1989, Schell et al. 1998).

Along environmental gradients these investigations confront several distinct challenges. The relative abundance of primary producers may vary considerably in space so that the availability of food sources to primary consumers at one end of the gradient may be very different to that at the other. The isotopic signature of individual primary producers may also vary across environmental gradients in response to environmental forcing on uptake of inorganic carbon and nitrogen sources (Kübler \& Raven 1994, Hurd 2000) or to variability among nutrient source pools (Cornelisen et al. 2007). Resolution of these 2 sources of variability is of utmost importance when using stable isotope analyses in food web studies that span environmental gradients.

In the present study we examined the spatial variation in isotopic signatures among primary producers and carbon flux to 2 common consumers along the axis of Doubtful Sound, a fjord with a strong freshwater and forest litter influx. We sampled across gradients in composition, abundance and variability in isotopic signatures within the macroalgal community. Sitespecific mixing models were then used to resolve the composition of diet in a grazing species, the sea urchin Evechinus chloroticus (Echinodermata: Echinoidea), as well as a detritivorous species, the sea cucumber Stichopus mollis (Echinodermata: Holothuroidea). The relationships between quality and composition of diet were compared with spatial patterns in growth rates and size structure for E. chloroticus (Wing et al. 2003b).

\section{MATERIALS AND METHODS}

Abundance of consumers. Study sites 1 to 5 were selected along the axis of Doubtful Sound (Fig. 1) to cross a range of surface salinity, wave exposure and irradiance conditions (Cornelisen et al. 2007). Stratified benthic surveys were undertaken at the 5 sites 


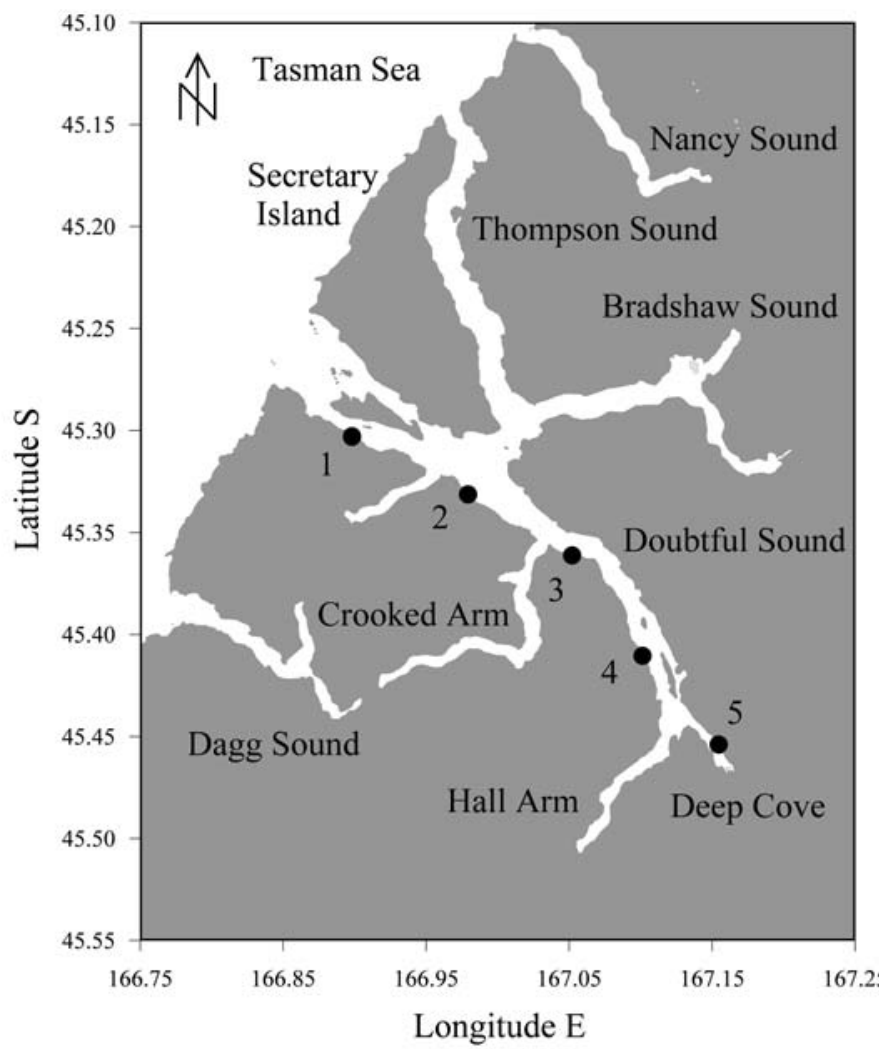

Fig. 1. Doubtful Sound study sites 1 to 5

during November 2002 and November 2004. At each site, 10 replicate quadrats $\left(2 \mathrm{~m}^{2}\right)$ were haphazardly positioned within each of 3 depth strata ( 0 to $5 \mathrm{~m}, 5$ to $10 \mathrm{~m}$, and 10 to $15 \mathrm{~m}$ ) by SCUBA divers, and the abundances of Evechinus chloroticus and Stichopus mollis were recorded. In the absence of a transformation that achieved normality, non-parametric Wilcoxon/ Kruskal-Wallis tests were used in lieu of ANOVA, followed by non-parametric multiple comparisons tests to resolve pair-wise differences in abundance among sites (Zar 1999).

Macroalgal biomass. Abundance and biomass estimates of macroalgae (Gracilaria sp., Gymnogongrus sp. and Cladophora sp.) from the LSL $(\mathrm{n}=300)$ and the most common large brown alga Ecklonia radiata $(\mathrm{n}=$ 260), were collected from the same set of 5 sites in Doubtful Sound using stratified random quadrats (Fig. 1). For the samples of biomass in the LSL community, 12 randomly placed $0.1 \mathrm{~m}^{2}$ quadrats were cleared of all macroalgae at each site using a Venturi tube sampler with a $333 \mu \mathrm{m}$ mesh bag to collect algae cleaned from each quadrat. Samples were separated by species and dried and weighed at the Portobello Marine Laboratory. Samples were collected from each site during 5 sample events bimonthly from January to September 2004 to obtain a measure of seasonal vari- ability. Biomass estimates of the perennial E. radiata at each site were obtained in April 2004 by collecting a series of twenty-five $2 \mathrm{~m}^{2}$ quadrats from each of 5 depth strata ( 0 to $5 \mathrm{~m}, 5$ to $10 \mathrm{~m}, 10$ to $15 \mathrm{~m}, 15$ to $20 \mathrm{~m}, 20$ to $25 \mathrm{~m}$ ) and random collections of 10 to 12 individual $E$. radiata from each site. Individuals were dried, weighed and estimates of biomass calculated from the survey data.

Site-specific variability in the seasonal biomass data for Ecklonia radiata, Ulva sp. and the most abundant estuarine species (Gracilaria sp., Gymnogongrus sp., Epymenia sp., Ceramium sp. and Cladophora sp.) were tested using a non-parametric Wilcoxon/Kruskal-Wallis as described for abundance of consumers.

Carbon source pools. Samples of Ulva sp., Gracilaria sp., Gymnogongrus sp., Epymenia sp., Ceramium sp. and Cladophora sp. $(\mathrm{n}=29)$ were collected in March 2004 for stable isotope analysis from the LSL, where they collectively comprise $>90 \%$ of the available biomass (K. L. Clark unpubl. data). Samples of Ecklonia radiata ( $\mathrm{n}=$ 14) were collected from depths of 10 to $15 \mathrm{~m}$ in April 2004. Site-specific isotopic data for each species were normalized to dry weight biomass and pooled to obtain an aggregate isotopic signature for macroalgae. Differences in $\delta^{13} \mathrm{C}$ and $\delta^{15} \mathrm{~N}$ of this aggregate isotopic signature were tested among sites using ANOVA.

Samples of suspended particulate organic material (SPOM) $(n=15)$ were collected from a series of 3 vertical plankton tows using a $50 \mu \mathrm{m}$ UNESCO plankton net from Sites 1, 3 and 5 (Fig. 1). Samples were screened $(200 \mu \mathrm{m})$ prior to filtering on pre-combusted Whatman GF/F filters and were stored at $-20^{\circ} \mathrm{C}$. Filters were dried at $60^{\circ} \mathrm{C}$ and packed into individual tin capsules. Samples of forest litter $(n=5)$ were collected from the Deep Cove delta (Site 5) and Sites 3 and 4 where vascular plant matter forms extensive detrital mats. Samples of macroalgae and forest litter were dried at $60^{\circ} \mathrm{C}$ and homogenized to a fine powder using mortar and pestle.

Tissue sampling of consumers. At each of the 5 sites, samples of 5 adult (80 to $110 \mathrm{~mm}$ test diameter) sea urchins Evechinus chloroticus were collected in 2002 and 2004 and immediately dissected. Muscle tissue was obtained from between the demipyramids of the Aristotle's lantern, and a $1.5 \mathrm{ml}$ sample was collected from the homogenized stomach contents. Concurrently, samples of 5 adult sea cucumbers Stichopus mollis were collected, and samples of muscle tissue were obtained from each individual. Each of the tissue samples were dried at $60^{\circ} \mathrm{C}$ and homogenized to a fine power using mortar and pestle.

Stable isotope analyses. Each of the macroalgae samples and consumer subsamples of 1 to $5 \mathrm{mg}$ were analyzed for $\delta^{13} \mathrm{C}$ and $\delta^{15} \mathrm{~N}$ at Iso-Trace NZ on a Europa 20-20 update stable isotope mass spectrometer (MS) 
(Europa Scientific) interfaced to a Carlo Erba elemental analyzer (NA1500) in continuous flow mode (precision: $0.2 \%$ ). Analysis was calibrated to EDTA laboratory standard reference (Elemental Microanalysis) and standardized against international standards (IAEACH-6 for carbon, IAEAN1 and IAEAN2 for nitrogen). Results are expressed in standard delta notation where, for example, $\delta^{13} \mathrm{C}=\left[\left(\mathrm{R}_{\text {sample }} / \mathrm{R}_{\text {std }}\right)-1\right] \times 1000$, where $\mathrm{R}_{\text {sample }}={ }^{13} \mathrm{C} /{ }^{12} \mathrm{C}$ and $\mathrm{R}_{\text {std }}={ }^{13} \mathrm{C} /{ }^{12} \mathrm{C}$ of Peedee belemnite limestone.

$\delta^{13} \mathrm{C}$ and $\delta^{15} \mathrm{~N}$ for muscle tissue of Evechinus chloroticus and Stichopus mollis were $\ln$ transformed to obtain normal distributions. Goodness of fit for these distributions were tested with a Shapiro-Wilks $W$ test. We tested for differences between sample periods and, in absence of significant differences, pooled samples across the 2 periods. Following transformation, ANOVA was used to test for differences in $\delta^{13} \mathrm{C}$ and $\delta^{15} \mathrm{~N}$ for each species among sites.

$\mathrm{K}$-means cluster analysis was carried out on $\delta^{13} \mathrm{C}$ and $\delta^{15} \mathrm{~N}$ of Evechinus chloroticus stomach contents, which defined (1) a cluster enriched in ${ }^{13} \mathrm{C}$ and ${ }^{15} \mathrm{~N}$ and (2) a cluster depleted in ${ }^{13} \mathrm{C}$ and ${ }^{15} \mathrm{~N}$. Regression analysis was then used to test the relationship between proportion of individuals in the cluster depleted in ${ }^{13} \mathrm{C}$ and ${ }^{15} \mathrm{~N}$ and the estimate of the fraction of stomach contents made up of terrestrial matter from the mixing model analysis (see below).

Mixing model. The multiple source mixing model 'Isoerror' (Phillips 2001, Phillips \& Gregg 2001) was used to estimate the contribution of the 3 primary carbon sources (macroalgae, SPOM and forest litter) to the Evechinus chloroticus and the Stichopus mollis assimilated diet, based on muscle tissue samples, and to estimate the composition of consumed diet of E. chloroticus, based on stomach content samples. For tissue samples of E. chloroticus and $S$. mollis the model was run in a 2-staged analysis. We used average values for incremental trophic enrichment of $\delta^{15} \mathrm{~N}(+2.4)$ and $\delta^{13} \mathrm{C}(+0.4)$ over 1 trophic level for E. chloroticus and 2 trophic levels for S. mollis (McCutchan et al. 2003) to estimate the relative contribution of these sources to diet. For the analysis of stomach contents of E. chloroticus, the same procedure was followed but no trophic enrichment was applied to $\delta^{13} \mathrm{C}$ and $\delta^{15} \mathrm{~N}$. First, the primary carbon sources, macroalgae, SPOM and terrestrial material, were analyzed. At sites where macroalgae dominated the diet (>95\%) we then used the mixing model to differentiate between macroalgal sources: Ecklonia radiata, Ulva sp. and LSL macroalgae (Gracilaria sp., Gymnogongrus sp. and Cladophora sp.). As E. radiata was absent at Sites 4 and 5, we used the mixing model to differentiate between Ulva sp., LSL macroalgae and forest litter. At Site 3, where E. radiata accounted for $<5 \%$ of diet, we again used the model to differentiate between Ulva sp., LSL macroalgae and forest litter.

Growth and size structure. We obtained information on the average asymptotic test diameter $\left(\mathrm{L}_{\infty}\right)$ of the Richard's growth model at each study region from Wing et al. (2003b). Information on the average test diameter of Evechinus chloroticus for each site was collected in the present survey. This was done by collecting and measuring test diameter of 197 to 677 (mean: 529) individuals from each site during the abundance surveys. Average test diameter was calculated from the size distribution. In each case, populations showed a unimodal size distribution. We used ordinary linear regression analysis to test the relationship among average test diameter, $\mathrm{L}_{\infty}$ and the difference between $\delta^{13} \mathrm{C}$ of muscle tissue and $\delta^{13} \mathrm{C}$ of stomach contents.

\section{RESULTS}

Macroalgal biomass. There were significant effects of site on biomass in the Wilcoxon tests on Ecklonia radiata $\left(\chi^{2}=26.35, \mathrm{df}=4, \mathrm{p}<0.0001\right.$, Sites $1^{\mathrm{a}}, 2^{\mathrm{a}}, 3^{\mathrm{b}}, 4^{\mathrm{b}}$ and $\left.5^{\mathrm{b}}\right)$, Ulva sp. $\left(\chi^{2}=14.40, \mathrm{df}=4, \mathrm{p}=0.0061\right.$, Sites $1^{\mathrm{a}}$, $2^{\mathrm{b}}, 3^{\mathrm{ab}}, 4^{\mathrm{ab}}$ and $5^{\mathrm{a}}$; sites not connected by the same letter are significantly different by Tukey's pair-wise comparisons) and the combined estuarine macroalgae group $\left(\chi^{2}=35.96, \mathrm{df}=4, \mathrm{p}<0.0001\right.$, Sites $1^{\mathrm{c}}, 2^{\mathrm{abc}}, 3^{\mathrm{b}}, 4^{\mathrm{ab}}$ and $5^{\mathrm{a}}$ ) (Fig. 2a).

Abundance of consumers. The results of non-parametric Wilcoxon/Kruskal-Wallis tests followed by nonparametric multiple comparisons indicated significant differences in abundances among sites in both Evechinus chloroticus $\left(\chi^{2}=13.7, \mathrm{df}=4, \mathrm{p}=0.0083\right.$, Sites $1^{\mathrm{ab}}$, $2^{\mathrm{a}}, 3^{\mathrm{ab}}, 4^{\mathrm{ab}}$ and $\left.5^{\mathrm{b}}\right)$ and Stichopus mollis $\left(\chi^{2}=38.89, \mathrm{df}=\right.$ $4, \mathrm{p}<0.0001$, Sites $1^{\mathrm{c}}, 2^{\mathrm{a}}, 3^{\mathrm{b}}, 4^{\mathrm{bc}}$ and $5^{\mathrm{bc}}$ ) (Fig. 2b).

Carbon source pools and stable isotope analysis. There were significant differences in $\delta^{13} \mathrm{C}$ and $\delta^{15} \mathrm{~N}$ by site for muscle tissue samples of Evechinus chloroticus $\left(\delta^{13} \mathrm{C}: \mathrm{r}^{2}=0.57, F_{4,73}=23.06, \mathrm{p}<0.0001\right.$; $\left.\delta^{15} \mathrm{~N}: \mathrm{r}^{2}=0.62, F_{4,73}=27.91, \mathrm{p}<0.0001\right)$. Tukey's post hoc tests indicated significant differences among sites for $\delta^{13} \mathrm{C}$ (Sites $1^{\mathrm{b}}, 2^{\mathrm{c}}, 3^{\mathrm{bc}}, 4^{\mathrm{bc}}$ and $5^{\mathrm{a}}$ ) and for $\delta^{15} \mathrm{~N}$ (Sites $1^{\mathrm{a}}, 2^{\mathrm{a}}, 3^{\mathrm{b}}, 4^{\mathrm{b}}$ and $5^{\mathrm{c}}$ ) (Fig. 3). There were also significant differences in $\delta^{13} \mathrm{C}$ and $\delta^{15} \mathrm{~N}$ by site for muscle tissue samples of Stichopus mollis $\left(\delta^{13} \mathrm{C}: \mathrm{r}^{2}=\right.$ $0.85, F_{4,48}=63.92, \mathrm{p}<0.0001 ; \delta^{15} \mathrm{~N}: \mathrm{r}^{2}=0.46, F_{4,48}=$ 9.44, $\mathrm{p}<0.0001)$. Tukey's post hoc tests showed that there were significant differences among sites for both $\delta^{13} \mathrm{C}$ (Sites $1^{\mathrm{a}}, 2^{\mathrm{a}}, 3^{\mathrm{a}}, 4^{\mathrm{a}}$ and $5^{\mathrm{b}}$ ) and $\delta^{15} \mathrm{~N}$ (Sites $1^{\mathrm{b}}, 2^{\mathrm{b}}, 3^{\mathrm{b}}, 4^{\mathrm{b}}$ and $5^{\mathrm{a}}$ ). There were also significant differences in $\delta^{13} \mathrm{C}$ and $\delta^{15} \mathrm{~N}$ by site for the aggregate macroalgal signature $\left(\delta^{13} \mathrm{C}: \mathrm{r}^{2}=0.18\right.$, $F_{4,157}=8.33, \mathrm{p}<0.0001 ; \delta^{15} \mathrm{~N}: \mathrm{r}^{2}=0.56, F_{4,157}=48.44$ ， $\mathrm{p}<0.0001)$. Tukey's post hoc tests demonstrated sig- 
nificant differences among sites for $\delta^{13} \mathrm{C}$ (Sites $1^{\mathrm{a}}, 2^{\mathrm{b}}$, $3^{\mathrm{b}}, 4^{\mathrm{ab}}$ and $5^{\mathrm{a}}$ ) and for $\delta^{15} \mathrm{~N}$ (Sites $1^{\mathrm{a}}, 2^{\mathrm{ab}}, 3^{\mathrm{b}}, 4^{\mathrm{c}}$ and $5^{\mathrm{d}}$ ) (Fig. 3). No significant relationships were observed among sites for isotopic signatures of the total fraction of SPOM or forest litter, so these were not included in Fig. 3.

Isotopic mixing model. Results of the mixing model analysis indicated dramatic differences among sites in the composition of macroalgal food assimilated by Evechinus chloroticus and demonstrated an increase in the use of vascular plant material at the innermost sites (Fig. 4a). Similarly, the mixing model analysis for Stichopus mollis indicated a shift from primarily kelp and estuarine macroalgae in the outer and mid-fjord sites to SPOM and vascular plant material in the inner fjord sites (Fig. 4b).

K-means cluster analysis on $\delta^{13} \mathrm{C}$ and $\delta^{15} \mathrm{~N}$ of Evechinus chloroticus stomach contents defined 2 distinct clusters, one enriched in ${ }^{13} \mathrm{C}$ and ${ }^{15} \mathrm{~N}$ and the other depleted in ${ }^{13} \mathrm{C}$ and ${ }^{15} \mathrm{~N}$. Cluster statistics indicated
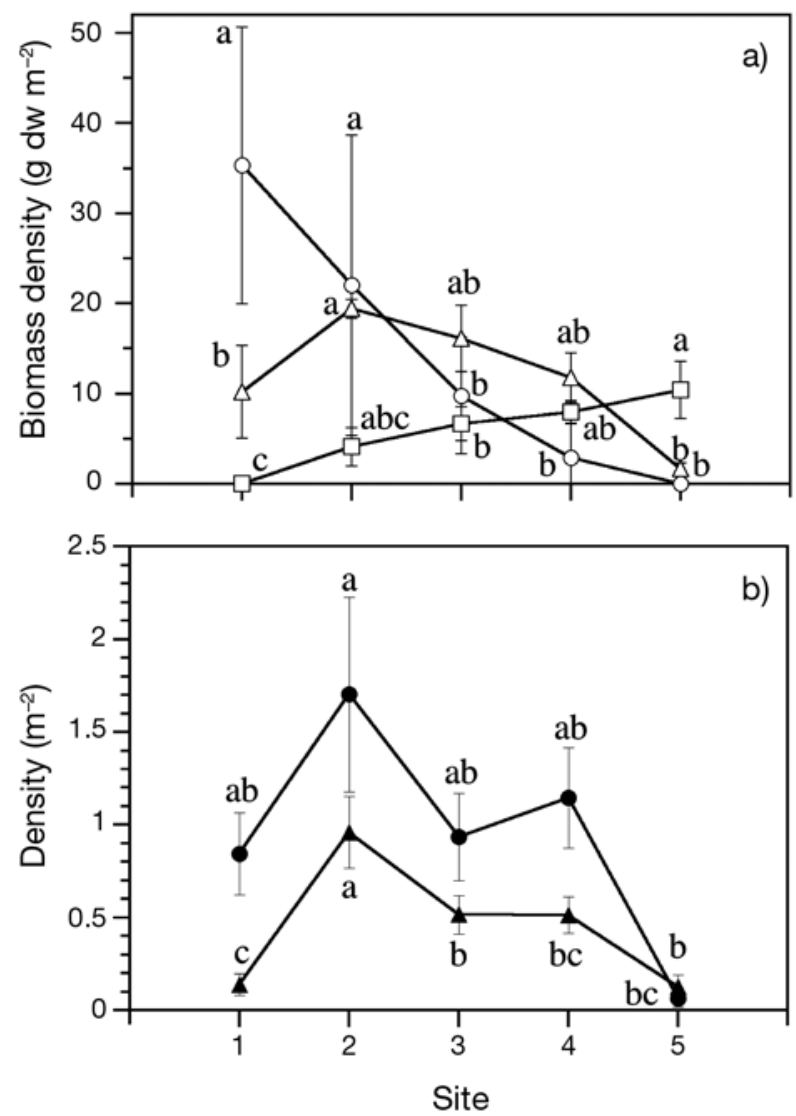

Fig. 2. (a) Biomass of macroalgae Ecklonia radiata (O), Ulva sp. $(\Delta)$ and combined LSL algae (Gymnogongrus sp., Gracilaria sp. and Cladophora sp.) ( $\square$ ) and (b) density of

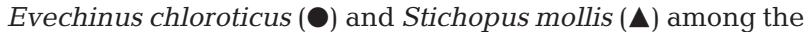
5 sites along the axis of Doubtful Sound. Error bars: \pm SE. Levels not connected by the same letter within each group are significantly different that there were 52 ind. in the first cluster (mean [SD]: $\delta^{13} \mathrm{C},-18.54 \%$ [2.87]; $\delta^{15} \mathrm{~N}, 2.96 \%$ [1.76]; maximum distance, 1.42) and 20 ind. in the second cluster (mean [SD]: $\delta^{13} C_{1}-29.99 \%$ [4.14]; $\delta^{15} \mathrm{~N},-1.79 \%$ [2.26]; maximum distance, 1.52) (Fig. 5). There was a significant relationship between the estimate of fraction of terrestrial material in the stomach contents samples $(x)$ and the proportion of individuals in the cluster depleted in ${ }^{13} \mathrm{C}$ and ${ }^{15} \mathrm{~N}(y)\left(y=0.59 x-0.058, \mathrm{r}^{2}=0.94, \mathrm{p}=0.0061\right)$ indicating a high level of assimilation of forest litter in the diet across the whole local population. This is particularly apparent in the inner fjord sites (Fig. 6).

Growth and size structure. Ordinary linear regression analysis revealed a strong relationship between test diameter, $\mathrm{L}_{\infty}$ and the difference between $\delta^{13} \mathrm{C}$ and $\delta^{15} \mathrm{~N}$ of tissue and stomach contents. There were significant relationships between (1) the average test diameter of Evechinus chloroticus by site $(x)$, and (2) average $\mathrm{L}_{\infty}$ of E. chloroticus by site $(x)$ and the difference between $\delta^{13} \mathrm{C}$ of stomach contents and muscle tissue (y): (1) $y=0.64 x+99.1, \mathrm{r}^{2}=0.14, \mathrm{p}=0.0009$; (2) $y=$ $0.79 x+102.7, \mathrm{r}^{2}=0.14, \mathrm{p}=0.0010$ ) (Fig. 7).
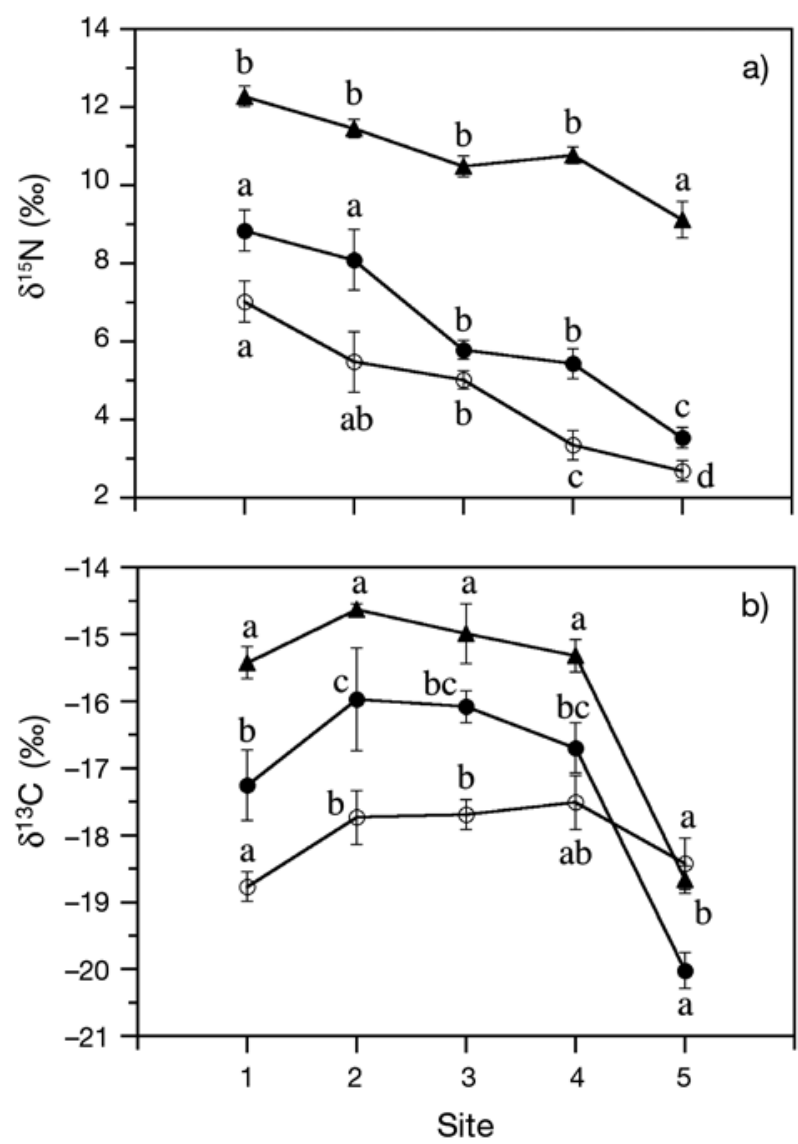

Fig. 3. (a) $\delta^{15} \mathrm{~N}$ and (b) $\delta^{13} \mathrm{C}$ for total macroalgae (O), Evechinus chloroticus $(\mathbf{O})$ and Stichopus mollis $(\mathbf{\Delta})$ among the 5 study sites. Error bars: \pm SE around the mean. Levels not connected by the same letter within each group are significantly different 


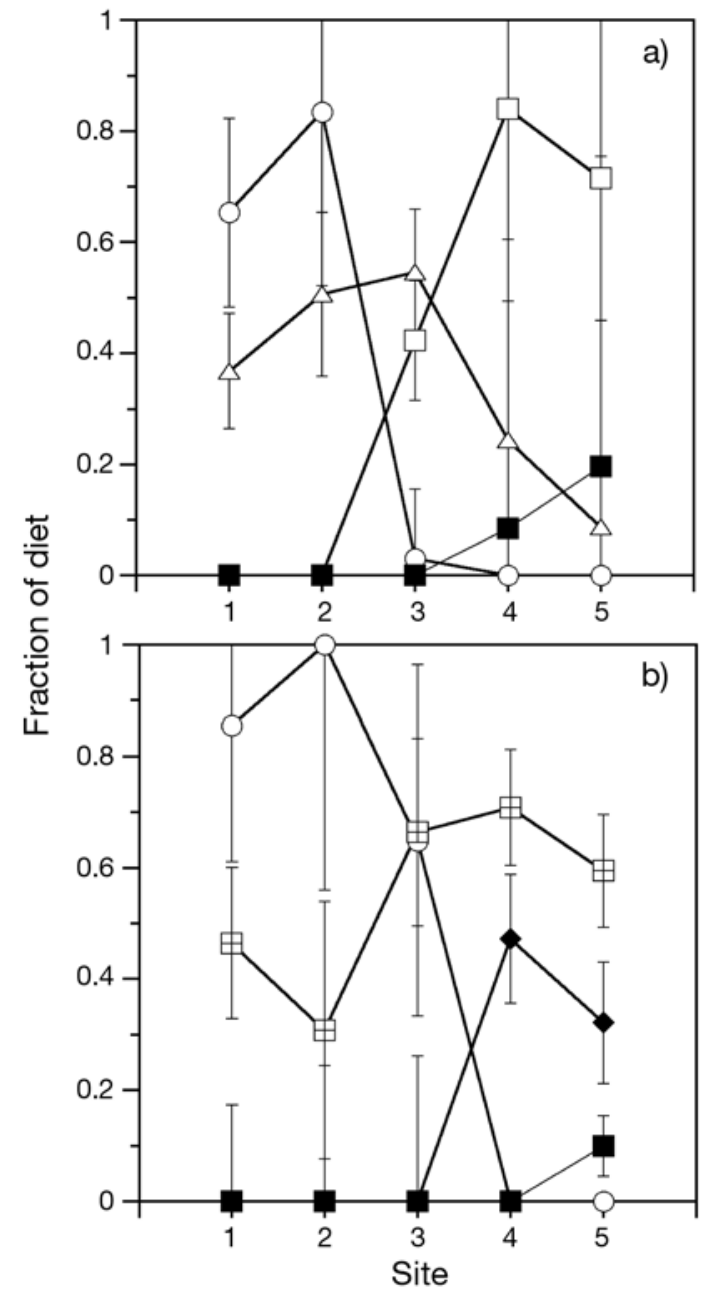

Fig. 4. Estimates of fraction of (a) Evechinus chloroticus diet made up of Ecklonia radiata (O), Ulva sp. $(\Delta)$, LSL macroalgae (Gymnogongrus sp., Gracilaria sp. and Cladophora sp.) $(\square)$ and forest litter (ם) and (b) Stichopus mollis diet made up of E. radiata (O), SPOM ( $\bullet$ ), total LSL macroalgae (Ulva sp., Gymnogongrus sp., Gracilaria sp. and Cladophora sp.) (田) and forest litter $(\mathbf{\square})$. Error bars: \pm SE

\section{DISCUSSION}

The results of the present study demonstrate that metapopulation structure of benthic marine invertebrates can be strongly influenced by bottom-up forcing at ecotone transitions. In the present example, this forcing is driven by strong gradients in the lability of available food for grazers and detritivores (Vadas 1977, Lamare \& Wing 2001). Specifically we show that the resource bases for both Evechinus chloroticus and Stichopus mollis vary strongly across the ecotone between outer coastal kelp-dominated habitats and those in the inner fjord where freshwater and terrestrial carbon sources predominate. This represents a large amount of plasticity in the diets of E. chloroticus and

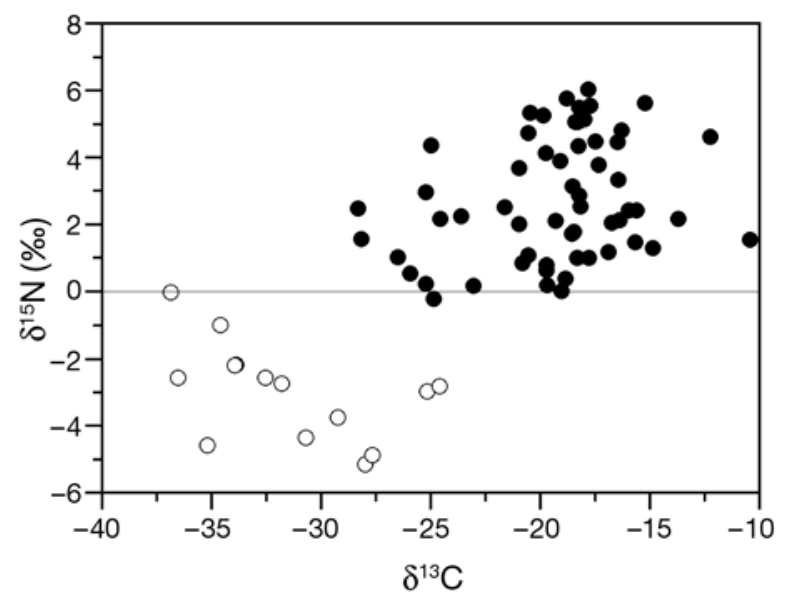

Fig. 5. Evechinus chloroticus. $\delta^{15} \mathrm{~N}$ and $\delta^{13} \mathrm{C}$ of stomach contents from the 5 study sites. (O): cluster of samples depleted in ${ }^{13} \mathrm{C}$ and ${ }^{15} \mathrm{~N}_{;}(\bullet)$ : cluster enriched in ${ }^{13} \mathrm{C}$ and ${ }^{15} \mathrm{~N}$
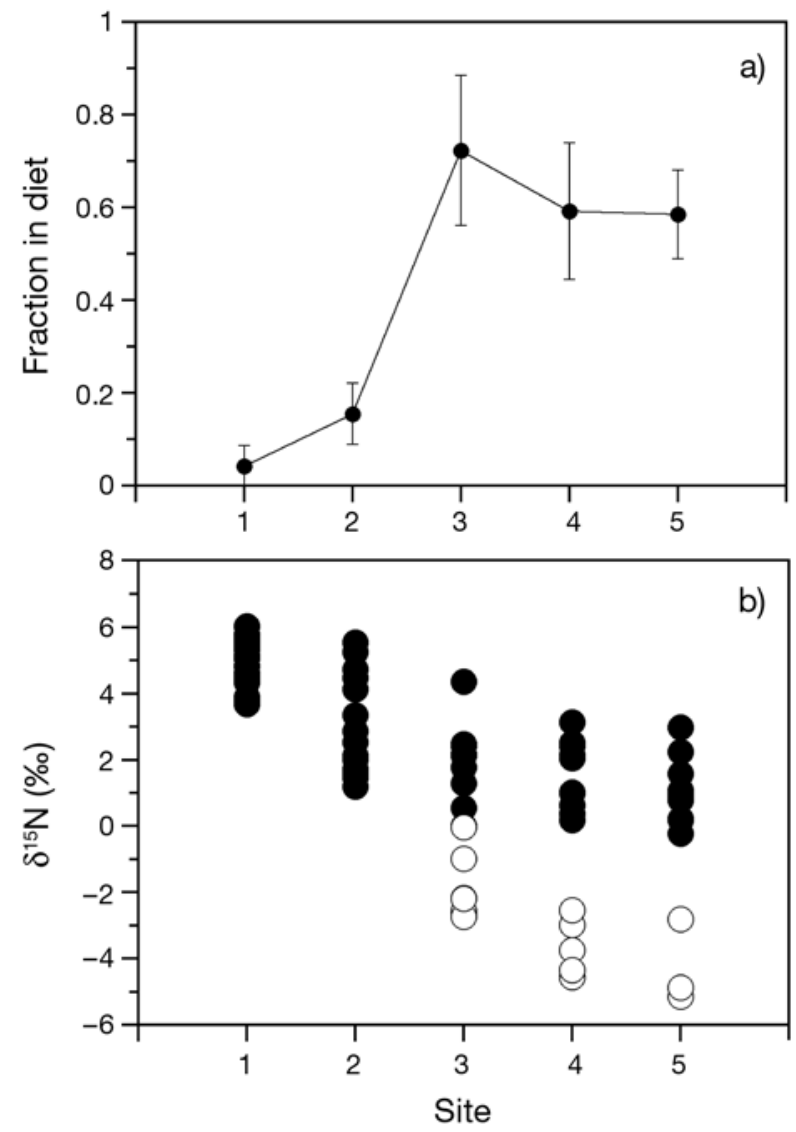

Fig. 6. Evechinus chloroticus. Estimate of (a) fraction of vascular plant material in stomach contents and (b) $\delta^{15} \mathrm{~N}$ of stomach contents by study site. (O): depleted cluster from Fig 5. Error bars indicate $\pm \mathrm{SE}$

S. mollis and the first evidence that these species are capable of making extensive use of terrestrially derived carbon sources though microbial recycling. The 


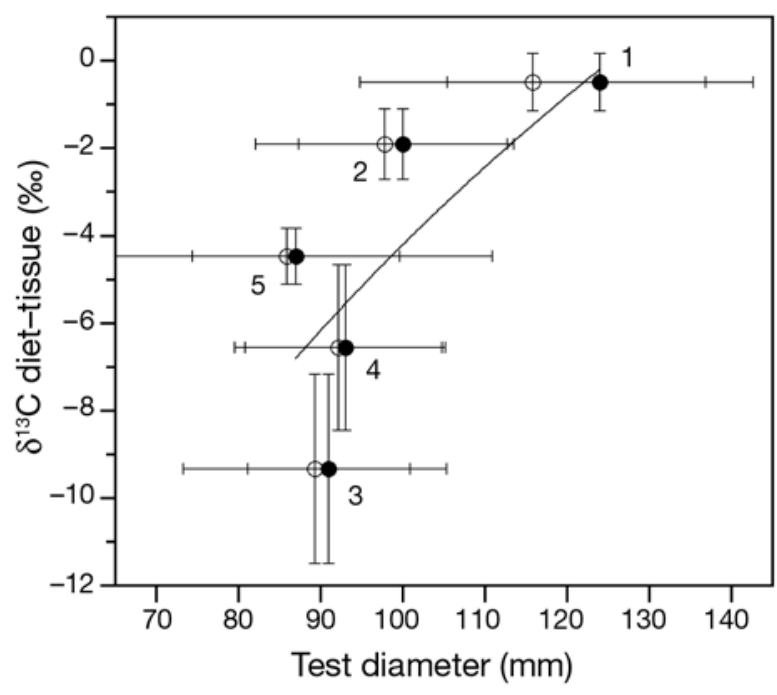

Fig. 7. Evechinus chloroticus. Relationship of the difference between $\delta^{13} \mathrm{C}$ of tissue and $\delta^{13} \mathrm{C}$ of stomach contents with $\mathrm{L}_{\infty}$ (-) from the Richard's growth model and average test diameter of the local population $(\mathrm{O})$ at the 5 study regions (symbols labeled by site number 1 to 5 ). Error bars: \pm SE

$\delta^{13} \mathrm{C}$ and $\delta^{15} \mathrm{~N}$ of $E$. chloroticus gut contents from the inner fjord sites were extremely depleted in ${ }^{13} \mathrm{C}$ and ${ }^{15} \mathrm{~N}$, consistent with the presence of large amounts of chemoautotrophic bacteria (McLeod \& Wing 2007). There is clear evidence that the irregular sea urchin Echinocardium cordatum has symbiotic gut bacteria and is able to assimilate complex carbohydrates and cellulose from vascular plant material (Brigmon \& de Ridder 1998, Thorsen 1999). However, it is not clear from our data from E. chloroticus whether this bacterial component of the diet is obtained from the sediment surface or from symbiotic bacteria in the gut.

Resolution of patterns in resource use was greatly aided by site-specific studies of the relative $\delta^{13} \mathrm{C}$ and $\delta^{15} \mathrm{~N}$ of the major carbon source pools within the fjord. In this example, site-specific resolution of isotopic signatures for each of the dominant macroalgal species were particularly critical for robust analysis of diet in the primary consumers. These data demonstrate that the isotopic signatures of macroalgae, a direct consumer of macroalgae Evechinus chloroticus and the detritivore Stichopus mollis vary significantly among sites along the axis of Doubtful Sound, while the isotopic signature of SPOM and forest litter are more consistent among sites. With these data, we were able to use a mixing model to estimate the relative contribution of macroalgae, phytoplankton and terrestrial material to the diets of these common consumers. We were then able to differentiate between 3 macroalgal groups in the diet of E. chloroticus. We found that there was increasing importance of refractory forest litter in the diets of E. chloroticus and S. mollis with distance into the fjord. Without site-specific analysis it would not have been possible to resolve diet in the primary consumers or the results would have been strongly confounded by isotopic variability within each primary producer species group. By using this extreme environmental gradient as a case study, we have highlighted the importance of resolving spatial variability in isotopic signatures for food web studies.

Cornelisen et al. (2007) demonstrated that in Ulva sp. much of the spatial variability in $\delta^{13} \mathrm{C}$ for macroalgae along the length of Doubtful Sound at these same study sites can be explained by the differential uptake of $\mathrm{CO}_{2}$ and bicarbonate. In this case, at belowsaturating irradiance, increases in irradiance lead to a greater demand for carbon and provide the needed energy for assimilating bicarbonate, a more abundant and isotopically heavier source of carbon than $\mathrm{CO}_{2}$ (aq). Thus, algal taxa capable of assimilating bicarbonate may have elevated (heavier) $\delta^{13} \mathrm{C}$ signatures under saturating irradiance relative to those under light-limited conditions, such as at the inner fjord sites (Wefer \& Killingley 1986, Kübler \& Raven 1994). Similarly, in wave-exposed sites on the outer coast where mass flux of $\mathrm{CO}_{2}$ is increased by hydrodynamic forcing of diffusional boundary layers at the algal surface, $\delta^{13} \mathrm{C}$ is depleted in ${ }^{13} \mathrm{C}$ (Cornelisen et al. 2007). These effects are also clearly seen in Ecklonia radiata across the gradient from the wave-washed and well-illuminated outer fjord habitats to the topographically shaded inner fjord habitats where light is limiting (Wing et al. 2007). Both of these mechanisms for differential use of inorganic carbon sources were reflected in the $\delta^{13} \mathrm{C}$ among sites for total macroalgae in the present study. $\delta^{15} \mathrm{~N}$ for Ulva sp. across this gradient varied primarily as a function of the nitrogen source pools, being terrestrially derived in the inner fjords $\left(\delta^{15} \mathrm{~N}, 0\right.$ to $2 \%$ ) and marine derived at the outer coast $\left(\delta^{15} \mathrm{~N}, 7\right.$ to $8 \%$ ) (Cornelisen et al. 2007). This pattern is observed in the present study for $\delta^{15} \mathrm{~N}$ of total macroalgae along the axis of the fjord. Together, these physiological mechanisms result in strong variability in $\delta^{13} \mathrm{C}$ and $\delta^{15} \mathrm{~N}$ along the axis of the fjord. Though the present study does not fully resolve temporal variability in $\delta^{13} \mathrm{C}$ and $\delta^{15} \mathrm{~N}$, this was found to be moderate compared with spatial variability in Cornelisen et al. (2007), and the algae used in the present study were collected during the autumn when reported values for $\delta^{13} \mathrm{C}$ and $\delta^{15} \mathrm{~N}$ were at intermediate levels.

Previous studies of the population structure of Evechinus chloroticus along the axis of Doubtful Sound have demonstrated that retention of larvae within the inner fjord was enhanced by the predominant estuarine circulation (Lamare 1998) and that growth (Lamare \& Mladenov 2000, Wing et al. 2003b) and reproduction 
(Lamare et al. 2002, Wing et al. 2003b) were depressed in the inner fjord habitats. These contrasting conditions for the 2 phases of the life history in E. chloroticus result in a strong source-sink structure within the populations in the fjords (Wing et al. 2003b).

An in-depth analysis of Evechinus chloroticus diet revealed that in the inner fjord a large component of the stomach contents was made up of forest litter. Paired samples of tissue and diet for these sites show that the vascular plant material may be made available to E. chloroticus by bacteria, either resident in the gut or on the sediment surface (Thorsen 1999). This was evidenced by the large quantities of woody debris found in the stomachs of sea urchins from the inner fjords, with values of $\delta^{13} \mathrm{C}$ and $\delta^{15} \mathrm{~N}$ consistent with sulfate-oxidizing bacterial signatures (e.g. $\delta^{13} \mathrm{C},-37 \%$ and $\delta^{15} \mathrm{~N},-5 \%$ ) for some stomach content samples (McLeod \& Wing 2007). This is a clear example of the importance of terrestrial material to recycled production by bacteria in the fjord and another pathway for this carbon source into the marine food web (McLeod \& Wing 2007).

The difference between $\delta^{13} \mathrm{C}$ of diet and $\delta^{13} \mathrm{C}$ of tissue for this species, an indication of assimilation efficiency, covaries with both the mean size and the asymptotic size $\left(\mathrm{L}_{\infty}\right)$, derived from growth studies of animals in the population. These results suggest that growth in this species is linked strongly to lability of carbon sources or food quality within local populations among sites along the ecotone. The pattern serves as a striking example of the influence of habitat quality in terms of food resources on vital rates of a benthic marine species and demonstrates that ecotones may exert strong influences on population structure and variability in carbon flux in coastal marine systems.

Acknowledgements. We thank M. Lamare, S. Rutger, S. Lusseau, J. Diehl, C. Perrin, C. Cornelisen, M. Sköld, the participants in Subtidal Ecology of Southern New Zealand (MARI 432) and the Departments of Marine Science and Chemistry at the University of Otago for assistance with this work. Monetary and logistic support was provided from the Royal Society of New Zealand's Marsden Fund to S.R.W. (UO-00213) and from the University of Otago.

\section{LITERATURE CITED}

Brigmon R, de Ridder C (1998) Symbiotic relationship of Thiothrix spp. with an Echinoderm. Appl Environ Microbiol 64: 3491-3495

Burrell D (1988) Carbon flow in fjords. Oceanogr Mar Biol Annu Rev 26:143-226

Cornelisen C, Wing S, Clark K, Bowman M, Frew R, Hurd C (2007) Patterns of macroalgal stable carbon and nitrogen isotope signatures: interaction between physical gradients and nutrient source pools. Limnol Oceanogr 52:820-832

> Deegan L, Garritt R (1997) Evidence for spatial variability in estuarine food webs. Mar Ecol Prog Ser 147:31-47
Dunton K, Saupe S, Golikov A, Schell D, Schonberg S (1989) Trophic relationships and isotopic gradients among arctic and subarctic marine fauna. Mar Ecol Prog Ser 56:89-97

Fry B (2006) Stable isotope ecology. Springer, New York

Hanski I, Gaggiotti O (2004) Ecology, genetics, and evolution of metapopulations. Elsevier Academic Press, Oxford

Hixon M, Pacala S, Sandin S (2002) Population regulation: historical context and contemporary challenges of open vs. closed systems. Ecology 83:1490-1508

Hughes J, Deegan L, Peterson B, Holmes R, Fry B (2000) Nitrogen flow through the food web in the oligohaline zone of a New England estuary. Ecology 81:433-452

Hurd C (2000) Water motion, marine macroalgal physiology and production. J Phycol 36:453-472

Kübler J, Raven J (1994) Consequences of light limitation for carbon acquisition in three rhodophytes. Mar Ecol Prog Ser 110:203-209

> Lamare M (1998) Origin and transport of larvae of the sea urchin Evechinus chloroticus (Echinodermata: Echinoidea) in a New Zealand fjord. Mar Ecol Prog Ser 174: $107-121$

Lamare M, Mladenov P (2000) Modelling somatic growth in the sea urchin Evechinus chloroticus (Echinoidea: Echinometridea). J Exp Mar Biol Ecol 243:17-43

Lamare M, Wing S (2001) Calorific content of New Zealand marine macrophytes. N Z J Mar Freshw Res 35:335-341

Lamare M, Brewin P, Barker M, Wing S (2002) Reproduction of the sea urchin Evechinus chloroticus (Echinodermata: Echinodea) in a New Zealand fjord. N Z J Mar Freshw Res 36:219-232

Machás R, Santos R (1999) Sources of organic matter in Ria Formosa revealed by stable isotope analysis. Acta Oecol 20:463-469

McCutchan J Jr, Lewis W, Kendall C, McGrath C (2003) Variation in trophic shift for stable isotope ratios of carbon, nitrogen, and sulfur. Oikos 102:378-390

McKee K, Feller I, Popp M, Wanek W (2002) Mangrove isotopic $\left(\delta^{15} \mathrm{~N}\right.$ and $\left.\delta^{13} \mathrm{C}\right)$ fractionation across a nitrogen vs. phosphorus limitation gradient. Ecology 83:1065-1075

McLeod R, Wing S (2007) Hagfish in the New Zealand fjords are supported by chemoautotrophy of forest carbon. Ecology 88:809-816

Miller S, Wing S, Hurd C (2006) Photoacclimation of Ecklonia radiata (Laminariales, Heterokontophyta) in Doubtful Sound, Fiordland. Phycologia 45:44-52

Nelson W, Villouta E, Williams G, Adams N, Slivsgaard R (2002) Marine macroalgae of Fiordland, New Zealand. Tuhinga 13:117-152

Peterson B (1999) Stable isotopes as tracers of organic matter input and transfer in benthic food webs, a review. Acta Oecol 20:479-487

> Peterson B, Fry B (1987) Stable isotopes in ecosystem studies. Annu Rev Ecol Syst 18:293-320

Peterson B, Howarth R (1987) Sulfur, carbon and nitrogen isotopes used to trace organic matter flow in the salt-marsh estuaries of Sapelo Island, Georgia. Limnol Oceanogr 32: $1195-1213$

Peterson B, Howarth R, Garritt R (1985) Multiple stable isotopes used to trace the flow of organic matter in estuarine food webs. Science 227:1361-1363

> Phillips D (2001) Mixing models in analysis of diet using multiple stable isotopes: a critique. Oecologia 127:166-170

Phillips D, Gregg J (2001) Uncertainty in source partitioning using stable isotopes. Oecologia 127:171-179

Post D (2002) Using stable isotopes to estimate trophic position: models, methods, and assumptions. Ecology 83: 703-718 
Ross A, Gurney W, Heath M, Hay S, Henderson E (1993) A strategic simulation model of a fjord ecosystem. Limnol Oceanogr 38:128-153

Rounick J, Winterbourn M (1986) Stable carbon isotopes and carbon flow in ecosystems. Bioscience 36:171-177

Rounick J, Winterbourn M, Lyon G (1982) Differential utilization of allochthonous and autochthonous inputs by aquatic invertebrates in some New Zealand streams: a stable carbon isotope study. Oikos 39:191-198

Saupe S, Schell D, Griffiths W (1989) Carbon-isotope ratio gradients in western arctic zooplankton. Mar Biol 103:427-432

Schell D, Barnett B, Vinette K (1998) Carbon and nitrogen isotope ratios in zooplankton of the Bering, Chukchi and Beaufort seas. Mar Ecol Prog Ser 162:11-23

Smith F (2001) Historical regulation of local species richness across a geographic region. Ecology 82:792-801

Smith F, Witman J (1999) Species diversity in subtidal landscapes: maintenance by physical processes and larval recruitment. Ecology 80:51-69

Southwood T (1977) Habitat, the template for ecological strategies? J Anim Ecol 46:337-365

Stanton B, Pickard G (1981) Physical oceanography of the New Zealand fiords. NZOI Mem 88:3-37

Thorsen M (1999) Abundance and biomass of the gut-living microorganisms (bacteria, protozoa and fungi) in the irregular sea urchin Echinocardium cordatum (Spatangoida: Echinodermata). Mar Biol 133:353-360

Editorial responsibility: Otto Kinne, Oldendorf/Luhe, Germany
Vadas R (1977) Preferential feeding: an optimisation strategy in sea urchins. Ecol Monogr 47:337-371

Wefer W, Killingley H (1986) Carbon isotopes in organic matter from a benthic alga Halimeda incrassata (Bermuda): effects of light intensity. Chem Geol 59:321-326

Wing S, Lamare M, Vasques J (2001) Population structure of sea urchins (Evechinus chloroticus) along gradients in primary productivity in the New Zealand fjords. In: Barker M (ed) Echinoderms: Dunedin. Balkema, Dunedin, p 575

Wing S, Botsford L, Morgan L, Diehl J, Lundquist C (2003a) Inter-annual variability in larval supply to populations of three invertebrate taxa in the northern California Current. Estuar Coast Shelf Sci 56:1-14

> Wing S, Gibbs M, Lamare M (2003b) Reproductive sources and sinks within a sea urchin, Evechinus chloroticus, population of a New Zealand fjord. Mar Ecol Prog Ser 248: $109-123$

Wing S, Leichter J, Perrin C, Rutger S, Bowman M, Cornelisen $C$ (2007) Topographic shading and wave exposure influence morphology and ecophysiology of Ecklonia radiata (C. Agardh 1817) in Fiordland, New Zealand. Limnol Oceanogr 52:1853-1864

Witman J, Grange K (1998) Links between rain, salinity, and predation in a rocky subtidal community. Ecology 79: 2429-2447

Zar J (1999) Biostatistical analysis. Prentice Hall, Upper Saddle River, NJ

Submitted: June 5, 2007; Accepted: January 29, 2008

Proofs received from author(s): May 15, 2008 